\title{
The Coded Language of HIV/AIDS: The Creative Use of Figurative Language in HIV/AIDS discourse in Gikuyu "Mukingo" songs and common-talk by public transport operators in Nyeri Town
}

Mary Kamunyu $^{1 *}$, Phylis Bartoo ${ }^{2}$

${ }^{1,2}$ Egerton University, Kenya

DOI: 10.36348/SIJLL.2019.v02i08.001

| Received: 13.10.2019| Accepted: 21.10.2019| Published: 27.10.2019

*Corresponding author: Mary Kamunyu

\section{Abstract}

This article interrogates the use of figurative language in HIV/ AIDS representations and framings in Gikuyu mukingo songs. The paper locates itself within the frameworks of Critical Discourse Analysis (CDA) and Systemic Functional Linguistics Theory (SFL) as the theoretical orientations to the article of HIV/AIDS discourse. The CDA primarily studies the way social power abuse; inequality and dominance are enacted, resisted and reproduced by text and talk in the social and political context, while the Systemic Functional Linguistics (SFL) offers a contribution of language in social situations centred predominantly on its relevance to functions, explanation and interpretation of the texts. These theoretical underpinnings served to examine the functions of informative, imperative and emotive in HIV/AIDS discourse. This paper adopted a cross-section design to help to describe the characteristics of the variables of the article. The article has been conducted among public transport operators in Nyeri town. Purposive and snowball sampling was used since randomization was impossible due to the lack of sampling frame as well as due to the mobile nature of public transport operators. Structured interviews and Focus Group Discussions (FGD) has been used for data collection. Data analysis was done using traditional thematic analysis. The findings of this article have shown that there is heavy use of figurative language in HIV/AIDS discourse in Gikuyu, which is culturally relevant. This language constructs sexuality and gender, depicting the role of masculinity and femininity in the HIV/AIDS spread. The HIV/AIDS discourse also constructs gender power inequalities that promote HIV/AIDS spread.

Keywords: figure of speech, mukingo songs, CDA, common-talk.

Copyright @ 2019: This is an open-access article distributed under the terms of the Creative Commons Attribution license which permits unrestricted use, distribution, and reproduction in any medium for non-commercial use (NonCommercial, or CC-BY-NC) provided the original author and source are credited.

\section{INTRODUCTION}

Despite vigorous campaigns on HIV/AIDS by the Kenyan government, the pandemic rages on. Whereas HIV/AIDS has been largely explained and addressed based on biomedical African HIV/AIDS discourse and African permissive sexuality theses, using Eurocentric communication modes, it is insufficient to explain the situation fully. In light of this reality, this article endeavours to unpack social constructions of HIV/AIDS discourse as expressed in Gikuyu vernacular through songs and common talk.

From the origin of the HIV/AIDS epidemic, numerous commentators have concerned themselves with issues of representing the disease and those people infected by it as much as with how to stop its spread. Language has a strong influence on attitudes toward HIV/AIDS and people infected and affected by HIV/AIDS [1]. Language, however, has been overlooked despite its significance as a major component in the fight against HIV/AIDS. Waitiki [2] adds that since the onset of HIV/AIDS pandemic, a lot has been written about it in terms of infection rates, impacts and ways of controlling its spread. Little if any has been written about language which is a powerful tool of communicating ideas, intentions and sentiments, among others. Language shapes the way we think about life. This article affirms that analyzing the language Kikuyu people use while talking about HIV/AIDS can provide helpful insights into the ways in which they perceive its dangers, preventive and management measures.

\section{LITERATURE REVIEW}

The language, words, metaphors, images and ideologies produced in the representation of HIV/AIDS have been a cause for debates from scholars in diverse fields. These commentators argue that the way in which 
HIV/AIDS is represented has serious implications regarding how the disease is perceived and how society treats people who are infected [3]. Thombre [4] in his research on 'Organizing Multiple HIV and AIDS Discourses for Engaging Crisis Communication in India' reveals that the HIV/AIDS discourses have a remarkable ability to generate meanings which is apparent when one examines the multiplicity of its interpretations. For instance, in India, HIV/AIDS is referred to as a disease of new untouchables [5]. In light with this view, this article will embark on a mission of unpacking various interpretations embedded in HIV/AIDS discourse through the use of figurative language. In addition, Thombre in his research concentrated on disengaging HIV/AIDS discourses in India in relation to fear, denial, and stigmatization, but did not examine the gender power relations which could not escape such an investigation. This article will move beyond mere language analysis to incorporate that replays of power dynamics between genders in HIV/AIDS discourse.

Horne [6] adds that the language of AIDS does not merely represent the condition: it constructs it in different ways. Words and images create different conceptual realities of the phenomenon. Discussion of AIDS is still a taboo in most African societies, essentially because of its relationship with the sexual act [7]. The subject of HIV/AIDS remains shrouded in mystery and is regarded as taboo, hence creating a culture of silence. This bars open dialogue on the subject. This article will examine how Kikuyu people conceptualize and talk about HIV/AIDS. This is meant to reflect their personal biases and/or lack of understanding. It also helps to explain their attitudes about HIV/AIDS.

Research by Mashiri et al. [8] on, 'Naming the Pandemic: Semantic and Ethical Foundations of HIV/AIDS Shona Vocabulary', found that the Shona people consider matters relating to sex, death, illness or other misfortune as taboo or unspeakable. Thus, the Shona people create and make use of numerous metaphors, euphemisms, slang and colloquial expressions for referring to HIV/AIDS or its consequences because they [9] buttresses this view when he affirms that traditional, as well as a modern society, encourages stylized communication that is distilled to obviate crisis and avoid open confrontation. On this account, this article will uncover the metaphors, euphemisms, allusions etc. employed by Kikuyu people in their songs to name issues surrounding HIV/AIDS that are deemed unspeakable.

The power of local languages to name HIV/AIDS pandemic has been challenged by Garrett's view that African languages lack words for expressing scientific thought and biomedical knowledge. Given that African languages seem devoid of scientific words or terms, diseases are given names that best reflect what people fear or feel [10]. Contrary to such a view, it is the position of this article that measuring any language's communicative efficacy in terms of the availability or non-availability of direct lexical equivalence with English words would be misleading. On this account, this article endeavours to examine how biomedical concepts surrounding HIV/AIDS are navigated through Gikuyu songs. The use of figurative language has been known to be common in HIV/AIDS discourse. Kangira et al. [11] in their research on the use of metaphors by women writers in Zimbabwe argue that the writers use metaphors to communicate various messages about HIV/AIDS and sex, in their discourse primarily because the Shona culture places restrictions on words and expressions which directly refer to HIV/AIDS and sex-related issues. This is assumed to enable ease comprehensibility of the message. Pongweni [12], on the contrary, has found that using analogies, metaphors and similes in HIV/AIDS discourse can lead to misconceptions, especially if people do not know the figurative concept. This means that using figurative language in HIV/AIDS discourse is a double-edged sword. It is the endeavour of this article to evaluate the comprehensibility of figurative language employed in HIV/AIDS discourse in Gikuyu songs. This shall be established through analysis of the respondents' interpretations of the symbolic entities encoded in those songs.

Since the first incident of HIV/AIDS was identified in Kenya in 1984, many metaphors and allusions have been created and used by various speech communities to communicate the message on the pandemic. But scholarly studies about metaphors used in relation to HIV/AIDS in general, if any, are very few [13]. In his research on 'Metaphors on HIV/AIDS Discourse among Oluluyia Speakers of Western Kenya' Kobia, discussed the metaphors related to HIV/AIDS used among various dialects of Oluluyia language. His analysis was limited to metaphors alone, but this article will examine other aspects of figurative language like similes, irony etc. as well as communicative strategies that weave these aspects into a unitary whole.

Another research on the use of figurative language in HIV/AIDS discourse was conducted by Magonya [14], 'On a Pragmatic Analysis of Figurative Language in HIV Discourse in Kenya. A Case Article of English and Kiswahili Messages' The research was a pragmatic analysis of the figurative language used in HIV discourse in Kenya with specific reference to Kiswahili and English AIDS posters. From her findings, she affirmed that chances of misunderstanding culturally unfamiliar metaphors in English and Kiswahili AIDS posters are high since Kenya comprises approximately forty-two (42) mutually unintelligible speech communities. Going by her findings, it can be deduced that use of Eurocentric modes, e.g. posters etc. in HIV/AIDS awareness creation has failed in its objective due to lack of comprehension of cultural 
metaphor as conveyed by English and Kiswahili. This article, therefore, opts to discuss the utility of using Gikuyu language in the construction of cultural metaphor surrounding HIV/AIDS discourse. Figurative language not only constructs the HIV/AIDS pandemic but also replays gender power dynamics in discourse. The review now proceeds to examine how gender power and sexuality is embedded in HIV/AIDS discourse.

\section{FINDINGS AND DISCUSSIONS}

The Interpretations of Figurative Language in HIV/AIDS Discourse in Gikuyu Songs

The societal discourse interweaves various linguistic vehicles to convey Agikuyu people's conceptualizations of the HIV/AIDS phenomenon. The use of figurative language in 'mukingo' songs and common talk among the public transporters reveals the Agikuyu's rich social, cultural and environmental contexts that inform the construction of HIV/AIDS discourse. In this article, an analysis of various linguistic devices used to convey peoples' interpretations, knowledge, attitudes, concerns and fears about HIV/AIDS phenomenon will be thoroughly examined.

\section{Use of metaphors to Describe HIVIAIDS Phenomenon}

As it happens in other language, metaphors are used to lubricate communication in Gikuyu. Steen [15] defines metaphors as invitations to understand one thing in terms of another. A metaphor is a kind of linguistic amelioration specifically designed to place taboo words and socially unacceptable forms. Rawson [16] argues that a metaphor is an outward and visible sign of people's inward anxieties, conflicts, fears and shame. The fear of causing psychic pain and the desire to be well thought of, guide people to use 'kind words'. The metaphors below depict various subjects and concepts that surround HIV/AIDS phenomenon.

\section{a) Metaphors on HIV/AIDS-Related to Funeral.}

1a. Murimu utari dawa $>$ Disease without cure.

1b. Mucii ugutuika maganjo> $A$ deserted homestead.

1c. Nigukahuruo ndarama> People will come and beat the drums.

From the metaphors (1a), (1b), (1c), one can easily conclude that HIV/AIDS is a fatal and catastrophic disease because it has no cure. By the virtue that it can clear homesteads; it means that it has the capacity to wipe away humanity. Therefore the metaphor of AIDS lacking cure implies that the disease is devastating, detrimental and injurious to the Agikuyu community and the nation at large. The expression kuhura ndarama (beating drums) implies singing dirges at a funeral, implying that contracting AIDS is a sure way of dying. According to Halliday's SFL, these metaphors play the informative function of informing us of the deadly social problem- HIV/AIDS.

\section{b) Metaphors on HIV/AIDS as a Self-Inflicted Disease}

2a. Uyu ni mucamio wa gwicutha> Selfflagellation.

2b. Guthaka pata pata pata potea> Gambling with one's life. The word, pata, which means 'get', and potea, 'to lose', are borrowed from Kiswahili.

2c. Guthie kuria irio ihiuhire> To go to cafes where delicious cuisines are served. 2d. Mwenda njeru> Hankering for new fortunes and never getting satisfied.

The metaphors (2a), (2b), (2c) and (2d) relate to a person's deviant behaviour. The idea that a person is involved in many sexual relations is expressed as, guthaka pata pata pata potea (gambling with one's life), which implies that the person is involved in many risky sexual unions. Also, the use of pata pata pata potea implies that the person is conscious of the inherent danger, but keeps on hoping that she/he'd not be infected. The use of the metaphor mucamio wa gwicutha (self-flagellation) implies one is willful engaging in risky behaviour automatically leading to contracting HIV/AIDS. The lexeme muchamio (whip), prove that HIV/AIDS is a very painful disease both psychologically and physiologically. The metaphor guthie kuria irio ihiuhire, which literally means to visit hotels and cafes where delicious cuisine is served, implies going to brothels and nightclubs to sample prostitutes. Going to such places is a deliberate and reckless way of putting oneself into the danger of contracting HIV. The same meaning is buttressed by the metaphor mwenda njeru, which literally means one always craving for new things. This metaphor implies people who are never satisfied with their sexual partners and are ever coveting other people's partners, a sure way of contracting HIV/AIDS. According to Halliday's SFL, these metaphors are informing us about the dangers of risky sexual behaviour.

\section{c) Metaphors of HIV/AIDS as Death}

3a. Kuhaicha bathi ya matuini> To board a bus to heaven.

3b. Gutonyerera thii> To sink into the earth.

$3 \mathrm{c}$. Kuria na rwa njora> To suffer the sword.

An infected person is regarded as being on a journey to death, as exemplified by the following metaphors. Death metaphor (3a), kuhaicha bathi ya matuini, which means that the person is on board by a heavenly bus to heaven, implies being in a dying process. The metaphor (3b), gutonyerera thii, which means to sink into the earth, implies that the person will die; the person is on his way to the grave. Once one gets infected with HIV/AIDS, the dying journey begins. This shows the permanence and irreversibility of 
HIV/AIDS; an outright death sentence. The metaphor (3c), kuria na rwa njora (to suffer the sword), implies that HIV/AIDS will slay its victim mercilessly. The metaphors have played an emotive function of creating fear and dread of contracting HIV/AIDS and the dying process.

\section{d) Metaphor of HIV/AIDS as a Foreign Disease \\ 4a. Murimu wa guuka $>A$ disease that came. \\ 4b. Murimu mweru> A new disease. \\ 4c. Murimu wa thiku ici $>$ Nowadays disease.}

There is a belief that HIV/AIDS pandemic came from somewhere going by the metaphor (4a), murimu wa guuka, which means a disease that came. The use of lexeme guuka (to come), is a sure way of 'othering' and distancing from this disease because the verb 'came' means HIV/AIDS has its origin somewhere. This has an aspect of belonging to someone, though the origin and 'owner' is unknown to Agikuyu people. The metaphor (4b), murimu mweru (a new disease), implies that this is a foreign and unprecedented illness; a disease not native to people. People perceive AIDS as a mysterious and baffling disease because it has no familiar historical antecedents. However, the metaphor (4c) murimu wa thiku ici (a nowadays disease), implies that HIV/AIDS is now a contemporary problem, and people are familiar with it. All these metaphors bear precautionary messages in the sense that AIDS is ubiquitous, and so people must be alert. According to SFL, these metaphors are informing us about the nature and existence of HIV/AIDS.

\section{e) Metaphors of HIV/AIDS as Lethal}

5a. Kurathwo ni rubora njuki> To be shot by a bee sting.

5b. Kurathwo ni igi > To be shot by a wasp sting.

5c. Kuhia ni mwaki wa gas> To burn by gas fire.

5d.Guthecwa ni muigua uri thumu $>$ To be pierced by a poisoned thorn.

5d. Kuorwo na chuma hiu> To be branded by a hot iron.

The terms kurathwo (shot/stung) and guthechwa (to be pierced), and kuorwo (to be branded) allude to the fact that AIDS is an excruciatingly painful, unbearable, unspeakable and deadly disease. In all these lexemes, HIV/AIDS is portrayed as an external problem that attacks one unawares. The veracity of these metaphors that HIV/AIDS is an external force beyond one's control is insufficient because people's willful and compulsive behaviour lead to contracting HIV/AIDS. The lexeme rubora (bee sting) in (5a) is known to cause untold pain and sufferings to its victim. The term muigua wi thumu (a poisonous thorn) in (5d), allude to the painful fatality of AIDS disease. The deadliness of AIDS is implied by verb kuhia (to burn) in (5c), especially by gas fire, which is unquenchable. AIDS will, therefore, ravage its victim like an inferno. The SFL emotive and informative functions show that
HIV/AIDS metaphors inform us about not only the sufferings attached to AIDS but also the surrounding fear and dread it causes

\section{f) Metaphors of HIV/AIDS as an Accident}

6a. Kunyua mai moru/maroge $>$ To drink polluted /poisoned water.

6b. Guturuka ngari kuguru ii ihenyaini $>$ A car tire burst on high speed.

6c. Gukinya mucumari utakuona > Stepping on a pointed nail unawares.

6d. Kugua irima utuku > To fall in a pit at night.

6e. Kuranga ikara > To step on hot coals.

In life, some accidents are avoidable, while others are unavoidable. From the metaphors given, one can easily conclude that HIV/AIDS is a disease that one contracts by accident. The metaphor (6b), guturika ngari kuguru ii ihenyani (a car tire burst on high speed), allude to unpredictability when and where HIV/AIDS infection may happen. However, the veracity of this metaphor is in question because by observing traffic rules and avoiding over speeding an accident can be avoided. The metaphor of 'tire bust' implies rash, risky sexual behaviour, which can be avoided by one being faithful to one's spouse, and avoiding many sexual partners. People should be careful on how they live their lives. This is articulated by the metaphor (6c), gukinya mucumari utakuona (stepping on a pointed nail unawares), which presupposes that HIV/AIDS is invisible. This metaphor acts as a warning and urges people to be extra vigilant in sexual matters. There are also metaphors of bad luck as expressed (6a), kunyua mai moru/maroge (to drink polluted/poisoned water) (6d), kuuga irima utuku (to fall in a pit), and (6e) kuranga ikara (to step on hot coals). Contacting HIV/AIDS could be perceived as a misfortune and illfate because the water may have been polluted deliberately by someone with an evil intention to harm, oblivious of the drinker. However, the water could have been poisoned without knowledge. Bad fortune could lead one to fall into a pit or step on hot coals. However, as a warning, people must drink their own water, or water they are sure of its purity. Also, as a warning, people must stop walking at night to avoid 'falling in the pit', and also walking barefooted to avoid 'stepping on hot coals'.

\section{g) Metaphors of HIV/AIDS as Calamity}

7a. Kiruhuho> Strong wind.

7b. Ngwa > Lightning.

7c. Kamugambo > An evil oracle/curse.

Metaphors of HIV/AIDS above reveal that the disease is a catastrophe that has hit the world. HIV/AIDS in metaphor (7a) and (7b) is depicted as catastrophic lightning and strong wind that causes devastating effects like death. Strong winds and lightning are environmental hazards that are occasionally found in places never seen before due to 
climatic changes. Just like strong winds and lightning, HIV/AIDS can occur any time; therefore, it is injurious and detrimental to many people. Just like a storm which will comb an entire region, HIV/AIDS does not discriminate. It can kill people of all walks of life. The metaphor (7c) kamugambo (an evil oracle/curse), show that HIV/AIDS is like a curse which follows certain bloodlines, causing them calamities. This interpretation is made, especially when an infected spouse infects his/her healthy partner and children are born with HIV. Eventually, the whole family is wiped off by AIDS. The people feel that whatever is happening is unnatural and a malevolent force could be behind that calamity. This embodies the Agikuyu cultural beliefs and worldview about mysterious scourges like HIV/AIDS, which are believed to be a curse. Such curses are believed to have an ability to destroy entire families and succeeding generations. AIDS is viewed not just a biomedical condition, but one with social and metaphysical dimensions. According to SFL, these metaphors have played an informative function of providing information, explanations and interpretations that HIV/AIDS pandemic is a social problem from an environmental and socio-cultural perspective.

\section{h) Metaphors of HIV/AIDS as a Journey}

8a. Mukingo ni rugendo> AIDS is a journey.

$8 \mathrm{~b}$. Ena tigiti wa matuini $>S /$ he has a heavenly ticket.

8c. Kuhaicha ngari njuru > To board a bad car.

8d. Ni mwethieri > He is a traveller.

From the metaphors supplied, it can be seen that HIV/AIDS can be expressed as a journey. The journey metaphor shows the beginning and end of a journey. Once infected with HIV, the journey to the grave begins. AIDS becomes a watershed and floodgate of so many 'journeys' all out to devastate and kill the victim in the most hopeless ways. The metaphor (8a) mukingo ni rugendo (AIDS is a journey) and (8d) $n i$ mwethieri (he is a traveller), reveal that once a person contracts HI-virus, he/she embarks on a complex journey to the grave. It is a complex journey because AIDS becomes a labyrinth of many intertwining journeys-journey of stigmatization, isolation, ostracization, sufferings, poverty and financial crisis. The metaphor (8b), ena tigiti wa matuini (s/he has a heavenly ticket) shows that contracting HIV/AIDS is a sure ticket of going to the grave. AIDS is also described in (8c) as kuhaicha ngari njuru (to board a bad car) that transports people to the grave. Like a car, HIV/AIDS has the capacity to carry many passengers to the grave. In addition, as a 'bad car, HIV/ AIDS can crash and end peoples tragically. It, therefore, means that HIV/AIDS kills masses of people, and it is important that people board 'good cars', implying avoiding risky sexual behaviour or multiple sexual partners. These metaphors play both informative and imperative function of SFL by sensitizing people on the gory sufferings of HIV/AIDS. i) Metaphors of HIV/AIDS as Creatures.

9a. Kiura kinene kia murio> A big 'chamelionfrog'. 9b. Nyamu njuru $>$ A bad animal.

9c. Nyoka ya githemba $>$ A strange snake.

9d. Irimu nene $>$ A big ogre.

9e. Mdudu/munyoo>A worm/vermin.

Metaphors used in relation to animals reveal both real and supernatural entities describe this AIDS pandemic. The metaphor (9a) uses animal imagery to enunciate HIV/AIDS discourse.

The frightening creature, kiura kinene kia murio (a big 'chamelionfrog) depict HIV/AIDS as a weird and unfathomable, hard to conceptualize entity that has the ability to ruin people's lives. A similar meaning is expressed by the metaphor (9c), nyoka ya githemba (a strange snake), which portray HIV/AIDS as a poisonous creature with an ability to kill its victim. However, the use of the lexeme githemba (strange) shows that HIV/AIDS is unprecedented and beyond people's imaginations. By describing AIDS as in (9b), as 'bad animal', the linguistic strategy of avoidance strategy relegates HIV/AIDS into no specificity. However, as a 'bad animal', HIV/AIDS is understood as an overwhelming and terrible monster that devours people's lives. A similar meaning is expressed by the metaphor (9d) irimu nene (big ogre), which implies that HIV/AIDS is a destructive and dangerous creature like ogres in Gikuyu myths that depict the malevolence of ogres towards humanity. By referring HIV/AIDS to mdudu/munyoo (a worm/vermin), shows that HIV/AID is an obnoxious parasite. Just like vermins and parasites that destroy crops and other materials, sometimes colonizing in the host slowly until they engulf the entire system, HIV/AIDS will cause the body to lose immunity, and finally one dies. The metaphors graphically paint HIV/AIDS as something very dreadful and fearsome, and so people are being warned to keep off from it. Such an unprecedented, mysterious and supernatural creatures baffle and staggers people's imaginations, making HIV/AIDS to be perceived as a mystery. The metaphors have played SFL emotive function of creating fear and dread about HIV/AIDS.

\section{Use of Personification}

2a. Kimiiri niaroka na niwe uyu urikuo> The crusher or guillotine is coming and already s/he is here.

2b. Kimiiri oigite mumirio mara muhuke thi yothe mumiroreire> The crusher has decreed that you be killed and get extinct.

2c. Ndaimono ni ciui kiria muigirwo, nikio kimiiri oigite mumirio mara > The devil knows your destiny, that why the crusher has said that your innards be strained. 
2d. Ngengere yauga mundu aumirie na karia mundu atuite > The bell has announced people to leave the farm with the coffee they have harvested.

\section{2e. Murogi okire utuku > Witch came at night.}

2f. Thii ino ni thukitio ni ciringi. Kihiu mwiri arenda gwitua kijana. No ngukwira mukingo ndui athuri> This world has been messed by money. Old men want to become youths. However, let me warn you AIDS does not care about elders.

From the figurative expressions above, HIV/AIDS is personified in (2a \&2b) as (kimiiri (crusher), (2c) as ndaimono (demons), (2d) as ngengere (bell), and (2e) as murogi (witch). As a 'crusher' HIV/AIDS is personified, as a ruthless entity with an ability to utterly destroy its victims. The use of the lexeme, ndaimono (demon) attributes to perceived supernatural and malevolent nature of HIV/AIDS. HIV/AIDS is personified as an ominous, weird and malicious destroyer by the use of the word as murogi (witch). HIV/AIDS has been personified as a human being by the expression ngukwira mukingo ndui athuri (let me warn you AIDS does not care about elders). HIV/AIDS does not discriminate in terms of age, sex or other social considerations.

The linguistic expression (2d), ngengere yauga mundu aumirie na karia mundu atuite (the bell has warned people to leave the farm with what they have harvested), borrowed from Agikuyu people coffee farming practice, implies that people should be satisfied with the risky sexual behaviours they have done so far, and should discontinue from further such acts. The warning message is that people should leave illicit sex relationships because of the danger of contracting HIV/AIDS. The linguistic expression (2e) murogi okire utuku (witch came at night) show that the virus 'walked' when the society was asleep, as suggested by lexeme $u t u k u$ (night), to show that people were ignorant and oblivious of the looming danger. The irony is that the kihiu mwiri ('sagacious' old men), trusted guardians and custodians of morality, have joined in the fray of spreading HIV/AIDS as expressed as, kihiu mwiri arenda gwitua kijana (old men want to become youths). This means that old men use their money to gratify their sexual lusts illicitly, thereby putting themselves and others into the risk of contracting HI/AIDS. So, HIV/AIDS has been personified as ndiui (does not 'know'/care) about people's age and any other social barriers. HIV/AIDS will infect and kill anybody in its path wantonly. The warning message from these forms of personification is that the entire society is at risk of being wiped out by HIV/AIDS if people will not be careful.

\section{Use of Rhetorical device}

3a. Nguria ni ciana cigana umuthi uyu itigitwo cia ndigwa? > I wonder how many children have been orphaned.

3b. Niandu aigana matunyitwo wendo wao wa muturire? > How many people are depressed and lost the joy of living? 3c. Airitu a thiku ici kai mendaga atia? > What
do girls of nowadays want?

3d. Ngari itari mbureki uramireka yume thome yaki? > Why do you let a car without breaks out of the yard?

3e. Wahura nyororoka ukuruini atia? Wahura mbira kwai wacereirwo ku? > How do you turn to boyish games in old age?

3f. Kigutha giki nguria hihi nuu ungihota kwigita? > I wonder who can evade this slingshot.

From the rhetorical questions (3a), I wonder how many children have been orphaned?', and (3b) 'how many people are depressed and lost the joy of living?, it is very baffling how HIV/AIDS has created an orphan generation by ravaging human societies leaving many folks disillusioned, despondent, and depressed. People have attracted this disaster to themselves as buttressed by the rhetorical question in (3d), why do you let a car without breaks out of the yard? The issue addressed by this question is why somebody who knows he/she lacks sexual restraint should go to places likely to ensnare him/her. This shows the danger of having such morally corrupt people mixing freely and likely to cause trouble in society.

The elderly people are also entangled in the cogs of this evil wheel of promiscuity when their moral standing has been queried in (3e) as wahura nyororoka ukuruini atia? (How do you turn to boyish games in old age?). These dangerous elders have subverted social order by retrogressing into childish and flirtatious behaviours. This implies the moral degradation and violation of social spaces that have enmeshed HIV/AIDS pandemic across different age barriers. The rhetorical question (3c), 'what do girls of nowadays want?' connotes gender inequality because young girls satisfy elderly men's sexual lusts. According to CDA, discourse does ideological work, representing, constructing, and reproducing unequal relations of power. In this rhetorical question, the issue implied is that the female is to blame gender for fuelling HIV/AIDS transmission. Therefore, HIV/AIDS has become a modern riddle of the sphinx where everybody is in wonder as expressed in (3f) as, kigutha giki nguria hihi nuu ungihota kwigita? (I wonder who can evade this slingshot.). The slingshot is on its trajectory 
smashing its target with devastating impact. The challenges that remain are how people will evade this 'slingshot' and remain uninfected in this risky world.

\section{Use of Diction}

4a. Mundu arumie kanyiri>Let a woman stick to her husband's small penis.

4b. Mundu arumie kagira> Let a man stick to his wifes' vagina.

4c. Mbeu njithi > Youthful seed meaning, young people.

4d. Kimera giki > This season/ crop, meaning this time we are living.

4e. Wakuhia ndakae kuga ndiareketie mundu > Whoever shall be burnt should not blame me that I never sent a warning.

4f. Muhuke thii yothe mwiroreire> You be wiped out from the face of the earth.

$4 \mathrm{~g}$. Ona rukuri ni ruroge $>$ Dried meat $($ grub) preserved in a honey barrel is poisoned. Rukuri is a euphemism for private parts.

4h. Iria ikuna kiugu no nginya inyue rubora. > Whoever that shall break out of the shed will surely receive the sting'. Rubora is a sting.

4i. Ngai gutiri mundu ungienda gutungana na nyoni njuru > God nobody would like to meet an evil bird.

4j. Nyoni njuru> Evil bird, meaning, a bad omen.

4k. Ngamini > A beauty.

41. Ndaguthaitha Ngai humbira, Shaitani wa kiunuhu ndakanyone> I implore you, God, hide me so that the malicious devil does not locate me.

HIV/AIDS discourse has utilised diction a great deal in constructing HIV/AIDS in Gikuyu. In metaphor (4b), the term 'kagira' refers to an exhausted sorghum head. This is to mean, let a man stick to his wife no matter how sexually exhausted she may be. The term kanyiri refers to a small penis. The diminutive prefix ka- is used to show a small and perhaps dysfunctional penis and vagina, shrunken with age. Nevertheless, the word of advice is that people should stick to their mates, no matter how sexually unsatisfying they happen to be, to avoid contracting HIV/AIDS. Words like mbeu njithi (youths), muhuke thii yothe mwiroreire (you be wiped out from the face of the earth), kimera giki (this season/ crop), and wakuhia ndakae kuga ndiareketie mundu (whoever shall be burnt should not blame me that I never sent warning), all point to an existing contemporary disease that is maliciously targeting the youths at their prime, and could make humanity extinct if it goes on unchecked. The use of the term kuhia (burn) portrays HIV/AIDS as a ravaging disaster. This shows that the disease is deadly, painful and fatal. The use of the word kuhuka (be extinct) is associated with 'harvest being scant', implies that humans will be decimated by AIDS: meaning dying in droves. AIDS is portrayed as genocide that is capable of decimating the entire human race. The warning is that HIV/AIDS is a relentless destroyer, and people should be very careful not to contract it.

The word rukuri (meaty delicacy) implies the most enticing part of the human body (sexual organs). Ironically, this 'meaty delicacy' it is infected with the HIV virus. The warning, therefore, is that iria ikuna kiugu no nginya inyue rubora (whoever shall break out of the shed will surely receive the sting). The word rubora (bee sting) implies being infected with $\mathrm{HI}$ virus). Rubora (bee sting) has an added meaning of HIV/AIDS being painful, injurious, and hurtful to people. The warning, therefore, is that people must remain in the shed, i.e. exercise moral safeguard to shield away infection. HIV/AIDS has also been referred to as nyoni njuru (evil bird, which means, bad omen). This 'evil bird' can meet with anybody anytime anywhere, and by implication, HIV/AIDS is therefore ill-fated, an ominous disaster caused by malevolent and supernatural powers. This depicts the helplessness and vulnerability of people in the face of the inevitability of contracting HIV/AIDS. HIV/AIDS is portrayed as kiunuhu (malicious), as it does not spare ngamini (beauties). This is a problem that needs divine help, besides biomedical intervention. This is expressed as ndaguthaitha Ngai humbira, Shaitani wa kiunuhu ndakanyone (I implore you God, hide me so that the malicious devil does not locate me). The worldview created by the use of these dictions show how Agikuyu people are grappling with this gigantic problem, and both physical and metaphysical interventions are invoked to offer a solution.

\section{Use of Biblical allusion}

5a. Andu aitu gwona 'mene mene pekeli peresin'. > My people, I see a writing on the wall, 'meme mene pekel persin'.

5b. Ngai tondu ni kwihia twihitie ugaturakarira, ririkana kwihokeka gwaku na kwa murugwo. > God since we have sinned against you with impunity, and now you are full of wrath, kindly consider your own faithfulness and that of your son Jesus Christ.

5c. Kihonia kia bururu uyu gitingioneka mibiraini. Kihonia kia bururi uyu kihithitwo mokoini maku.> The panacea for this nation cannot be found in condoms. The healing for this nation is hidden in your arms.

Biblical allusions reveal how people construct religious explanations about the HIV/AIDS phenomenon. HIV/AIDS is perceived as divine retribution by the use of the expression like andu aitu gwona mene mene pekeli peresin (my people I see writing on the wall: meme mene pekel persin). These words appeared on King Nebuchadnezzar's, the 
Babylonian King wall to warn him of impending judgement due to his insolence. Sooner, God's judgement befell him, and he left his throne for the wild where he was banished from the human race for seven years to eat grass like cattle. The HIV pandemic is, therefore constructed to be a divine judgement and punishment for people's sin of promiscuity and sexual deviance. This realisation that HIV/AIDS is caused by divine retribution due to immorality has led people to seek divine intervention as expressed, Ngai tondu ni kwihia twihitie ugaturakarira, ririkana kwihokeka gwaku na kwa murugwo (God since we have sinned against you with impunity, and now you are full of wrath, kindly consider your own faithfulness and that of your son Jesus Christ). However, this theodicy discourse seems to contradict medical discourse when it says that kihonia kia bururu uyu gitingioneka mibiraini (The panacea for this nation cannot be found in condoms). Condoms then are portrayed as gadgets and instruments of immorality which are not useful solutions in fighting the pandemic. The question that begs answer is, if the condom were never there at all, how gory would the situation of HIV/AIDS be in this nation? HIV/AIDS as a social problem seems to introduce other moral problems like 'condoms use' as seen from religious lenses as promoters of immorality. The world view created is that people should just abstain from illicit sex to avoid contracting HIV/AIDS.

\section{Satire \& Humour}

10a. Mwanake hau uthiete niho twaturaga. No tukiuma ho twetaga mwathani na mihehu. $>$ Young man where you are treading, behold we all walked there. By the time we were decamping, we had pleaded the Lord in whispers.

10b. Indo ciitu niho cianywireire kagera. Tukiuma ho twahuraga nugu na mahiga.> That is where we lost our wealth. As we left, we stoned monkeys in despair.

10c. Gicagini nakuo karikari, kaigaci na kumi kumi ciuragite arume marungo. Atumia no kugirika.> In the villages, local brews have sapped men's virility. Women are moaning and grumbling.

10d. Mwanake aranogio ni njamuthi cio ukuru mbere ya gukawe.> Young men are ageing faster than their grandfathers.

The folly of exposing oneself to a situation where one can contract HIV/AIDS is being ridiculed. In expression (10a \&10b), young men are being warned to desist going to prostitutes who will defraud them money and infect them with HIV/AIDS. They are warned that some mindless boys who visited prostitutes lamented that, 'by the time we were decamping, we pleaded the Lord in whispers' because of the loses they suffered. The same humour goes on to show the deplorable scenario where alcohol has reduced men to dummies, and there is sex crisis facing their wives. In (10c.), the 'in the villages, local brews have sapped men's virility; women are moaning and grumbling'. Young men 'are ageing prematurely before their grandfathers' due to alcohol abuse. This social quagmire becomes a recipe for disaster because aggrieved wives will seek redress in illicit sexual relationships exposing themselves and their alcoholic husbands to HIV/AIDS. The world view is that alcohol has an auxiliary link to HIV/AIDS spread, and the warning is that people should rethink such habits of alcohol consumption.

\section{Symbolism}

11a. Mwanake uyu rora gikabu wega, ndukehenie uthire rui wagwata thamaki utwarire nyukwa.> "Young man, check your basket very well. Do not fool yourself that you went fishing, but you present to your mother a chameleon frog".

11b. Karagita ti hunyu ni mumunyirire wa thangari.> The fame of a tractor is not in colour (dusty brown) but its power to uproot couch grass.

The business of looking for a wife has been symbolised as fishing, and the lexeme rui (river) is the society where these fish exist. The danger inherent in this fishing expedition is that one may catch a mysterious creature called kuria kia murio (chameleonfrog), which symbolises a woman infected with HIV/AIDS. The message is directed to the male gender to be very vigilant on whom they take as a sexual partner. By implication, the social ideology constructed is that female gender is feared to be infected with HIV/AIDS, thereby endangering men. Ironically, the fisherman could be the one infected with HIV/AIDS and end up infecting a 'healthy fish' with it while 'eating' it. This social ideology of men 'fishing' and 'eating' women construct gender exploitation and abuse. Ironically this discourse purports that female gender is the staple food for men and at the same time agent of HIV/AIDS spread. Such social ideology constructs men as vulnerable victims of women. This is a case of gender imbalance in HIV/AIDS discourse.

In (11b), men have been symbolised as karagita (tractor). The import in this symbolism is the horsepower of a tractor equates to men's virility. The tractor is hailed for its energy and performance. It should not be underrated because it is dirty. This symbolism has put a high stake on male sexuality and identity, almost idolising it. In terms of sexual prowess and virility, men are likened to a tractor that ploughs the land and uproots thangari (couch grass), which implies thorough and excessive lovemaking. Women are described as farms' to be 'ploughed'. According to 
CDA, discourse does ideological work, reproducing unequal relations of power. The social ideology of male supremacy is constructed because as men demonstrate the 'horsepower of their tractors', they expose themselves and women to HIV/AIDS infection. This discourse exalts masculine superiority and sexual prowess as big tags of male identity. By positioning men as sex conquerors and women as their victims, this discourse positions gender imbalance within HIV/AIDS discourse.

\section{CONCLUSION}

As it can be deciphered from the foregoing, people have relied on the use of figurative language when discussing, talking about HIV/AIDS in Nyeri Town. In the paper, the societal discourse revealed various linguistic vehicles for conveying Agikuyu people's conceptualizations of the HIV/AIDS phenomenon. The use of figurative language in 'mukingo' songs and common talk among the public transporters reveals the Agikuyu's rich social, cultural and environmental contexts that inform the construction of HIV/AIDS discourse. In this paper, an analysis of various linguistic devices like metaphors, irony, syllogism, symbolism, among others indicated peoples' interpretations, knowledge, attitudes, concerns and fears about HIV/AIDS phenomenon.

\section{REFERENCES}

1. Brown, P.(2001). "Interventions to Reduce HIV/AIDS Stigma: What have we Learned?" Retrieved from http:www popcouncil.orgs/pdfs/horizons/lirvstigdisc.pdf

2. Waitiki, S. (2009). Language as a tool of stigmatization, discrimination and marginalization in Response to HIV/AIDS in Kenya. Maarifa Journal of Humanities and Social Sciences, 3(2), 117-128.

3. Anyango, O. P. (2012). Representations of HIV and AIDS in Nyanza Province, Kenya. International Journal of Humanities and Social Science, 2(11), 8-66.

4. Thombre, A. (2007). Organizing multiple HIV and AIDS discourses for engaging crisis communication in India. In Matthew W., Seeger, Timothy L. Sellnow, \& Robert R. Ulmer (Eds.).
Crisis Communication and Public Health. (pp.179199). Cresskill, NJ: Hampton Press.

5. Singhal, A., \& Vasanti, N. P. (2005). The role of popular narratives in stimulating the public discourse on HIV and AIDS. South Asian Popular Culture. 3(1), 3-15.

6. Horne, F. (2004). Some Aspects of AIDS-related Discourse in Post-Apartheid South Africa Culture. Alternation, 11 (2). 401-419.

7. McFadden, P. (1992). Sexuality and the problem of AIDS in Africa. In Meena, R. (Ed.). Gender in Southern Africa: Conceptual and theoretical issues. Harare: Sapes Books.

8. Mashiri, P., Mawomo, K., \& Tom, P. (2002) Naming the pandemic: Semantic and ethical foundations of HIV/AIDS Shona vocabulary. Zambezia 31(11), 221-234.

9. Pfukwa, C. (2001). "Unwritten Ethics and Moral Values: The Human Face of Chimurenga II". In: Vambe, T.M.ed. Orality and Cultural Identities in Zimbabwe (pp 25-36). Gweru: Mambo Press.

10. Garrett, L. (2000). 'AIDS in Africa: Lexicon of Fear.' Retrieved from Newsday.com.

11. Kangira, J., Mashiri, P., \& Gambahaya, Z. (2007). Women writers' use of metaphor as gender rhetoric in discourse on HIV/AIDS and sex-related issues: The case of Totanga Patsva (We start afresh) by Zimbabwe Women Writers. Nawa Journal of Communication, 1(1), 31-45.

12. Pongweni, A. J. C. (1989). Figurative language in Shona discourse: A study of the analogical imagination. Harare: Mambo Press.

13. Kobia, J. M. (2008). Metaphors on HIV/AIDS discourse among Oluluyia speakers of Western Kenya. Critical Approaches to Discourse Analysis across Disciplines, 2(2), 48-66.

14. Magonya, L. (2012). A pragmatic analysis of figurative language used in HIV/AIDS discourse in Kenia: a case study of English and Kiswahili messages. (Thesis) Université de Genève. Retrieved from https://archiveouverte.unige.ch/unige: 19452

15. Steen, Gerard. (2008). The Paradox of metaphor: Why we need a three-dimensional model of metaphor. Metaphor and Symbol, 23(4). 213-241.

16. Rawson, H. (1981). A dictionary of euphemism and other double talks. New York, NY: Crown Publisher, Inc. 